\title{
Genotoxicity of paracetamol on the germ cells of Drosophilla melanogaster
}

\author{
Saleha Y. M. alakilli \\ Department of Biology, Faculty of science, King Abdelaziz University, \\ Saudi Arabia
}

\begin{abstract}
Paracetamol is a common analgesic and antipyretic drug. The aim of the present study is to determine the potential genetic effects of Paracetamol in Drosophilla melanogaster using two methods: Sex Linked Recessive Lethals (SLRL) test and effect of Paracetamol on enzyme activity using spectrophotometric analysis. Three concentrations of drug were used $(5,10$, and $20 \mathrm{mM}$ ). The results reveal significant differences in S.L.R.L, except spermatozoa stages showed insignificant increases when the data of the four broods were considered all together in three treatments. Meanwhile, Paracetamol showed a genotoxic effects in the three categories of the two generations of S.L.R.L, F1 heterozygous females, F2 bar eye females and F2 wild type males on the genetic back ground of Cholinesterase in all treatments.
\end{abstract}

\section{Introduction}

Excessive consumption of any analgesic compound can produce harmful unwanted effects. It is now well established long term ingestion of analgesic compounds may result in analgesic nephropathy with impaired renal function. Paracetamol has been used extensively as an analgesic and antipyretic drug. Several reports have indicated genotoxic effects of Paracetamol. It was reported that Paracetamol also causes chromosomal aberrations in Chinese hamster fibroblast cells in vitro [Ishidate and Yqshikawa, 1980]. Paracetamol has been shown to induce liver-cell tumours in mice after long- term feeding (Flaks and Flaks, 1983), and to induce DNA damage in mouse-liver cells in culture (Dybing et al., 1984). Dunn et al ., 1987 were found that Paracetamol induced micronuclei in ratkidney fibroblasts. In vivo and in vitro experiments were discovered that Paracetamol inhibits both replicative DNA synthesis and DNA repair synthesis animals. It is also causes DNA damages and increases the frequency of chromosomal aberrations in mammalian cell lines and isolated human Lymphocytes [Hongslo et al., 1990, Hongslo and Holme, 1994, Rannug et al., 1995]. Tapadia and Lkhotia (1997) were investigated the specific induction of the hsr omega heat shock gene locus of Drosophilla melanogaster by Paracetamol. Furthermore, Skorpen et al. (1998) demonstrated that Paracetamol increases sensitivity to ultraviolet (UV) irradiation, delays repair of the Uracil - DNA glycosylase and recovery of RNA synthesis in human keratinocyte cells. In some animals, small doses of paracetamol are toxic [Allen, 2003]. Walubo et al. (2004) said that coadministration of Paracetamol with inhibitors of cytochrome P450 prevented the development of Paracetamol- induced hepatotoxicity in rats. Also, Ucheya and Igweh (2006) suggested that histological changes in kidney structure follwing a longterms administration of Paracetamol (Acetaminophen) in pregnant Sprague Dawleg rats, induces toxicity revealed by induced hyperacidity in combination with acute or chronic inflammation (Rainsford and White house, 2006). However, Because of the wide availability of paracetamol there is a large potential for overdose and toxicity [Pardale et al., 2006 and Pardale, 2007]. The present study was carried out to investigate the nature of the response of Drosophilla melanogaster male germ cells to three concentrations of Paracetamol (acetami-nophen) using the well known Muller-5 technique for the detection of sex 
Linked recessive lethal mutations and the estimation of the activity of the cholinesterase enzyme $(\mathrm{ChE})$ in three categories of the two generations of S.L.R.L.

\section{Material and Methods.}

\section{Strains:}

Two strains of D.melanogaster were used in the present study:

\section{a-Muller-5 (M-5):}

A marker strain of D. melanogaster used for the detection of Sex Linked Recessive Lethal mutations. Its Xchromosome carries a dominant marker bar eye (B) and a recessive mutant eye color, white apricot $\left(\mathrm{w}^{\mathrm{a}}\right)$. It has also two inversions, the first is scute $\left(\mathrm{Sc}^{8 r}\right)$ inversion and the second designated (in-s), is included in the first inversion.

\section{b-Oregon- $R(O-R)$ :}

This stock is a wild type strain that has always been used in Drosophila laboratories. It was obtained from the department of Genetics, An Shams University, Cairo, A.RE. This strain was repeatedly tested to determine its spontaneous Sex-linked recessive lethal (S.L.R.L).

\section{Chemicals:}

a- Paracetamol ( $N$-(4-hydroxyphenyl) ethanamide) is a popular and common analgesic and antipyretic drug used for relieving fever, headaches, and other minor aches and pains.

b- Cholinesterase Detection Kit

Estimation of the activities of the enzyme Cholinesterase (CHE) from QUIMICA CLINICA APLICADA.

\section{Methods:}

Two test systems were used:

a-Mullar (1972) and Brusick (1980) for Drosophila Sex Linked recessive lethal (SLRL) assay.

b-The estimation of the activity of the enzyme Cholinesterase (ChE) in Drosophila melanogaster.

In this investigation, (O-R)of D.melanogaster males were treated on a medium contained three concentration of paracetamol $(5,10 \& 20 \mathrm{mM})$ and detection of SLRL.

Also three categories were analyzed for enzyme activity: F1 females heterozygous, $\mathrm{F}_{2}$ females and wild type males.

\section{Statistical Analysis:}

1- For sex-linked recessive lethal, the kasten baum and Bowman test was used to test significance of the results (Wurgier et al., 1975).

2- As significance test for enzyme estimation, ANOVA test (SPSS program).

\section{Results and Discussion}

\section{a. Induction of Sex-Linked Recessive Lethal:}

As can be seen in Table (1) the results obtained from the SLRL test after treatment with three concentrations of Paracetamol $(5,10$ and $20 \mathrm{mM})$. The data show that the three concentrations of Paracetamol induced SLRL mutation except spermatozoa stages showed insignificant increases when the data of the four broods were considered all together in three treatments. This result suggests a mutagenic effect of Paracetamol in the induction of sex Linked recessive Lethals in Drosophila melanogaster. This is in agreement with the results obtained by many other laboratories. Tapadia and Laxhotia (1997) reported that Paracetamol was induced a high rate of transcription at the hsr omega heat shock gene in polytene chromosomes of Drosophila melanogaster. Genotoxic effects of Paracetamol have been demonstrated both in vitro and in vivo, the data indicated that Paracetamol may contribute to an increase in the total burden of DNA-damage in man (Hongslo and Holme, 1994). Hongslo et al. (1991) and Hongslo et al. (1994) investigated the genotoxicity of Paracetamol in mice and rats. The results suggested that Paracetamol induced DNA damaged. Also, Brunborg et al. (1995) found that Paracetamol interferes with nucleotide excision repair in several mammalian cell types, and may contribute to genotoxicity in humans. Moreover, Bergman et al. (1996) reported that paracetamol causes chromosomal damage 
in vitro in mammalian cells at high concentrations. Furthermore, Mendoza et al. (2003) investigated the effects of D-003, a mixture of high molecular weight primary acids from sugar cane, on Paracetamol induced liver damage in rats.

Aganovice- Musinovic et al. (2004) suggested that Paracetamol had mutagenic potential in Allium cepa. Also, brulj et al. (2007) demonstrated that Paracetamol concentration of $200 \mathrm{mug} / \mathrm{ml}$ expresses certain genotoxic effects in human peripheral blood lymphocytes. On the other hand, National toxicology program (1993) reported that $\mathrm{p}$-Nitrophenol (production of paracetamol) was not mutagenic in Salmonella typhimurium with or without exogenous metabolic (S9) activation, or in germ cells of male Drosophila melanogaster. Also, in Chinese hamster ovary cells, no induction of sister chromatid exchanges was observed with or without S9, but a significant increase in chromosomal occurred in trials conducted with S9.

\section{b. Mutagenic effect of Paracetamol on the enzyme activity.}

The second part of this investigation was carried out to estimate the activity of ChE enzyme in some insects of two generation of SLRL: F1 females F2 bar eye females and F2 wild type male. Table2 showed that Paracetamol caused changes in
ChE activity due to its mutagenic potentiality and it can be easily notice that lowest values of the activity of the $\mathrm{ChE}$ were observed with the three concentrations of drug. The $\mathrm{ChE}$ activity was 22846 units in the control group of F1 females while they decreased to $13992,15536.5$ and 14238 units under the effect of $5 \mathrm{mM}, 10$ $\mathrm{mM}$, and $20 \mathrm{mM}$, of Paracetamol treatments respectively in F1 females. Similar results were obtained from F2 bar eye females and F2 wild type males. Statistical analysis indicated that the differences of F1 females, F2 females and F2 males with the control were highly significant. This result is in agreement with Loewenstein et al., (1993), who observed that carbamate compouneds led to a drop of $\mathrm{ChE}$ in Drosophila melanogaster. Data for $\mathrm{ChE}$ in $\mathrm{F} 1$ and $\mathrm{F} 2$ females were more variable than thouse in F2 male which was noticed in $5 \mathrm{mM}$ concentration of Paracetamol. This would suggest that $\mathrm{ChE}$ activity may be polygenic trail, which is in accordance with the findings of Salam et al., (1995) and Al- Twaty, (2004). The data of the two test systems for mutagenicity indicated that Paracetamol used in the present study had mutagenic potentiality on the genetic background. However, further experiments are needed to discover the possible role of maternal and genotypic modifying effects.

Table 1: Identification of sex linked recessive lethals occurring spontaneously and after different treatments with paracetamol in D.melanogaster

\begin{tabular}{|c|c|c|c|c|c|c|c|c|c|c|c|c|c|c|c|}
\hline \multirow{2}{*}{ Treatments } & \multicolumn{3}{|c|}{$\begin{array}{l}\text { Sperms } \\
\text { B1 }\end{array}$} & \multicolumn{3}{|c|}{$\begin{array}{l}\text { Spermatides } \\
\text { B2 }\end{array}$} & \multicolumn{3}{|c|}{$\begin{array}{c}\text { Spermatocytes } \\
\text { B3 } \\
\end{array}$} & \multicolumn{3}{|c|}{$\begin{array}{c}\text { Spermatogonia } \\
\text { B4 }\end{array}$} & \multicolumn{3}{|c|}{ Total } \\
\hline & $\mathrm{N}$ & $\mathrm{L}$. & $\%$ & $\mathrm{~N}$. & $\mathrm{L}$. & $\%$ & $\mathrm{~N}$. & $\mathrm{L}$. & $\%$ & $\mathrm{~N}$ & $\mathrm{~L}$. & $\%$ & N. & $\mathrm{L}$. & $\%$ \\
\hline Control & 982 & 2 & 0.20 & 1080 & 1 & 0.09 & 1029 & 1 & 0.01 & 810 & 2 & 0.25 & 3901 & 6 & 0.15 \\
\hline $\begin{array}{l}\text { Paracetamol } \\
5 \mathrm{~m} \mathrm{M}\end{array}$ & 865 & 6 & 0.7 & 784 & 3 & $0.38 *$ & 437 & 3 & 0.69 & 344 & 1 & $0.3^{*}$ & 2430 & 13 & 0.53 \\
\hline $10 \mathrm{~m} \mathrm{M}$ & 793 & 6 & 0.76 & 724 & 2 & $0.28 * *$ & 69 & 4 & $0.58^{*}$ & 562 & 2 & $0.36^{*}$ & 2772 & 12 & 0.43 \\
\hline $20 \mathrm{~m} \mathrm{M}$ & 751 & 4 & 0.53 & 635 & 2 & $0.31 * *$ & 591 & 3 & $0.51 *$ & 598 & 3 & $0.5^{*}$ & 2575 & 12 & 0.47 \\
\hline
\end{tabular}

N. = Number of tested chromosomes, L. = Number of lethal mutations (SLRL), \%=Frequency of

SLRL.; Pslevel of significant

Significance: $* \mathrm{P}<0.05$ and $* * \mathrm{P}<0.01$ 
Table 2: Effect of Paracetamol with different treatments on Cholinesterase (ChE) activity in three categories of $D$. melanogaster

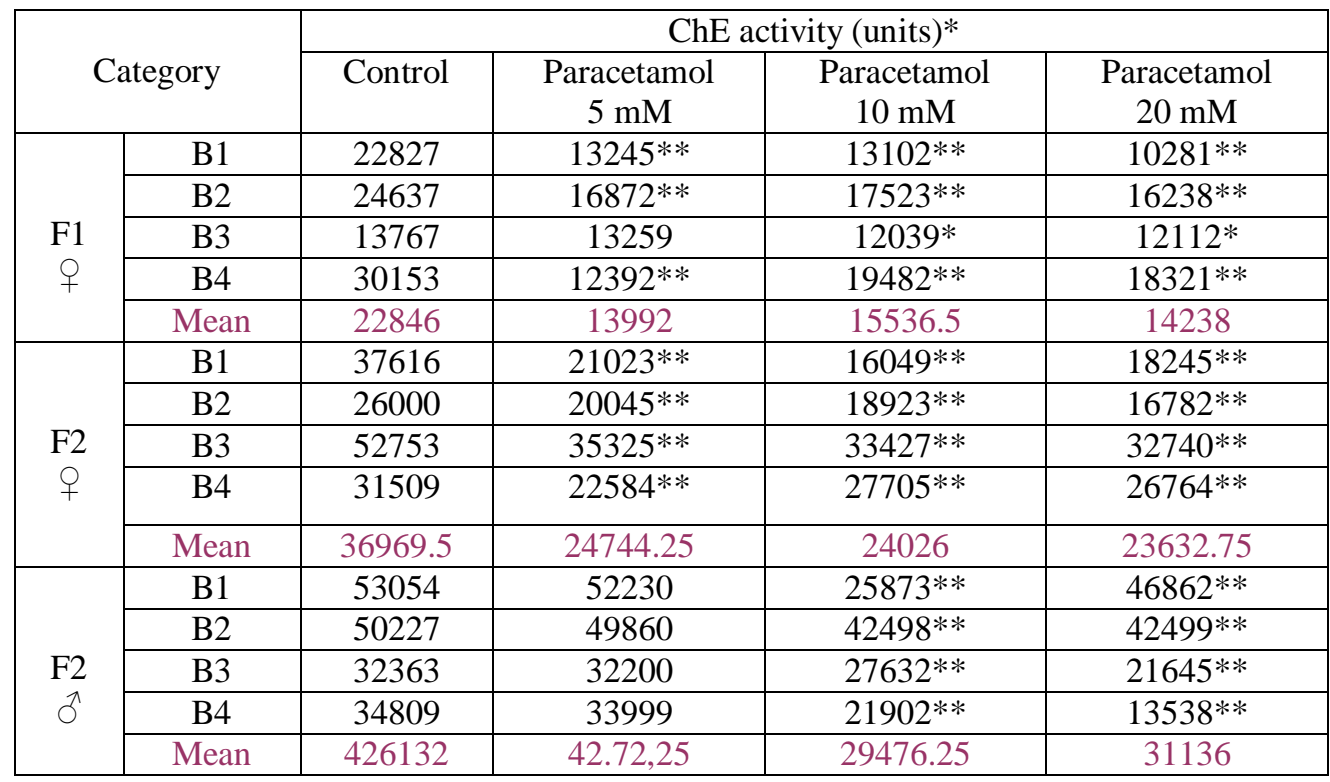

*One unit of ChE activity is expressed one Ug of activity choline (substrat) reacting with $\mathrm{ChE}$ in on $\mathrm{ml}$ of 100 flies homogenate in one hour incubation at $37^{\circ} \mathrm{c}$.

Significance: $* \mathrm{P}<0.05$ and $* * \mathrm{P}<0.01$

\section{References}

1. Aganović-Musinović I Todić M Becić F and Kusturica J (2004): Genotoxicity evaluation of paracetamol applying Allium test, Med Arh.;58(4):206-209.

2. Allen A L (2003): The diagnosis of acetaminophen toxicosis in a cat, Can. Vet. J., 44 (6): 509-510.

3. Al-Twaty N H (2004): Study of genotoxic effect of Lorazepam (ativan) on Drosophila melanogaster, JKAU: Sci., 16: 9-20.

4. Bergman K, Müller $\mathbf{L}$ and Teigen $\mathbf{S}$ W (1996): Series: current issues in mutagenesis and carcinogenesis, No. 65. The genotoxicity and carcinogenicity of paracetamol: a regulatory (re)view. Mutat. Res., 349(2):263-288.

5. Brunborg $G$ and Holme J K (1995): Inhibitory effects of paracetamol on DNA . repair in mammalian cells, Mutat. Res., 342(3-4):157-170.

6. Dunn T L, Gardiner R A, Seymour G J and Lavin M F (1987): Genotoxicity of analgesic compounds assessed by an in vitro micronucleus assay. Mutat. Res., 189 (3): 299 - 306.

7. Dybing E, Holme J A, Gordon W P, Soderlund E J, Dahlin D C and Nelson S
(1984): Genotoxicity studies with paracetamol., Mutat Res., 138 (1): 21-32.

8. Flaks A and Flaks B (1983): Induction of liver cell tumours in IF mice by Paracetamol, Carcinogenesis, 4 (4):363368.

9. Hongslo J K, Brøgger A, Bjørge C and Holme J A (1991): Increased frequency of sister-chromatid exchange and chromatid breaks in lymphocytes after treatment of human volunteers with therapeutic doses of Paracetamol, Mutat. Res., 261(1):1-8.

10. Hongslo J K, Bjorge C, Schwarze P E, Brogger A, Mann G, Thelander $L$ and Holme J A (1990): Paracetamol inhibits replicative DNA synthesis and induces sister chromatid exchange and chromosomal aberrations by inhibition of ribonucleotide reductase. Mutagenesis., 5 (5): 475 480.

11. Hongslo J K and Holme J A (1994): [DNA damages caused by paracetamol] Tidsskr Nor Laegeforen., 114(10):1204 1206. Review. Norwegian.

12. Ibrulj S, Rahmanovic A, Haveric S, Haveric A and Pasic A D (2007): Cytogenetic evaluation of paracetamol 
effects in human lymphocytes culture. Drug Chem Toxicol.;30(2):133-143.

13. Ishidate M Jr and Yoshikawa K (1980): Chromosome aberration tests with Chinese hamster cells in vitro with and without metabolic activation--a comparative study on mutagens and carcinogens, Arch. Toxicol., 4: 41-44.

14. Loewenstein $\mathbf{Y}$, Denarie M, Zakut $\mathbf{H}$ and Soreq H (1993): Molecular dissection of cholinesterase domains responsible for carbamate toxicity. Chem. Biol. Interact., 87(1-3):209-216.

15. Mendoza $S$, Noa $M$, Mas $R$ and Mendoza N (2003): Effect of D-003, a mixture of high molecular weight primary acids from sugar cane wax, on paracetamol-induced liver damage in rats. Int $\mathbf{J}$ Tissue React., 25(3):91-98.

16. National Toxicology Program (1993): NTP Toxicology and carcinogenesis studies of p-Nitrophenol (CAS No. 100-02-7) in Swiss Webster Mice (Dermal Studies)., Nati. Toxicol. Program Tech Rep. Ser., 417: 1-161

17. Rainsford and White house (2006): Paracetamol [acetaminophen]-induced gastrotoxicity: revealed by induced hyperacidity in combination with acute or chronic inflammation. Inflammopharmacology, 14(3-4):150-154.

18. Pardale-V Tablets (2006): Presentation, UK. National Office of Animal Health. Compendium of Animal Medicines, 1-3.
19. Rannug U, Holme J A, Hongslo J K and Sram R (1995): International Commission for Protection against Environmental Mutagens and Carcinogens. An evaluation of the genetic toxicity of Paracetamol, Mutat Res., 327 (1-2): 179-200.

20. Salam A Z, El Abidin, De-Hondt H A, Fahmy M T, Soussa S F, Elngar T F and Ahmed E S (1995): The mutagenicity of Nudrin and Meothrin on two different Eukaryotic systems "Drosophilla and Yeast" Annals. Agric. Sci., Ain Shams Univ., Cairo, 40 (2): 737-751.

21. Skorpen F, Alm B, Skjelbred C, Aas P A and Krokan H E (1998): Paracetamol increases sensitivity to ultraviolet (UV) irradiation, delays repair of the UNG-gene and recovery of RNA synthesis in HaCaT cells. Chem Biol Interact. 12: 123-136.

22. Tapadia M G and Lakhotia S C (1997): Specific induction of the hsr omega locus of Drosophila melanogaster by amides. Chromosome Res., 5(6):359-362.

23. Ucheya $R \mathbf{E}$ and Igweh J C (2006): Histological changes in kidney structure following a long-term administration of paracetamol (acetaminophen) in pregnant Sprague Dawley rats, Niger. J. Physiol. Sci., 21(2):77-81.

24. Walubo A, Barr S, Abraham A M and Coetsee C (2004): The role of cytochrome-P450 inhibitors in the prevention of hepatotoxicity after paracetamol overdose in rats, Hum. Exp. Toxicol., 23 (1):49-54. 


\title{
السمية الوراثية لعقار الباراسيتامول على الخلايا الجرثومية لحشرة الاروسوفيلا ميلانوجاستر الخاريا
}

\author{
صالحه يحيى محمد العقيلي \\ قسم علوم الأحياء- كلية العلوم- جامعة الملكي عبد العزيز

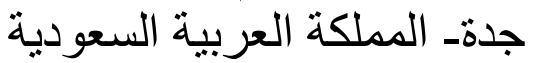

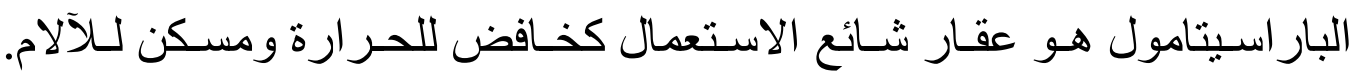

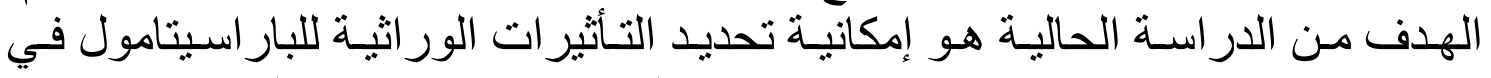

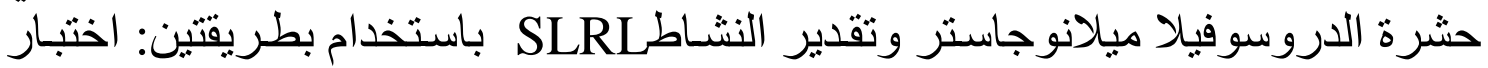

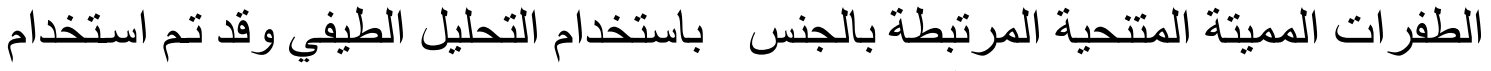
تالاثة ChE الإنزيمي لإنزيم كولين استريز

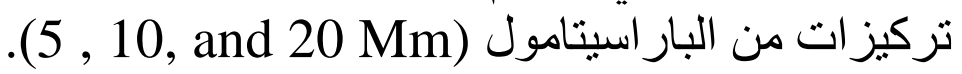

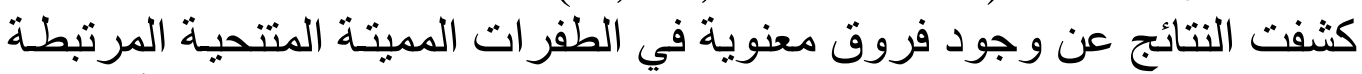

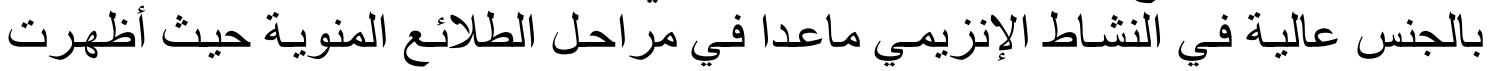
فروق غير معنوية لكلا الجيلين وكانت متساوية في المعاملاتلات الثيلاثلة.

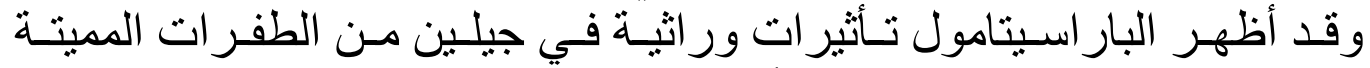

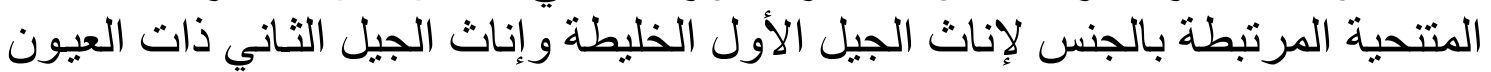

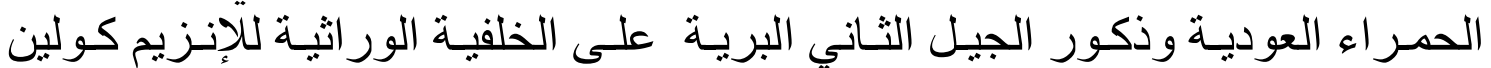

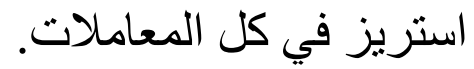

